\title{
Ediciós do Castro e Editorial Cuco-Rei (1963-1978)*
}

\author{
Ediciós do Castro and Editorial Cuco-Rei (1963-1978)
}

\author{
María Antonia PÉRez RodRíguez \\ Universidade da Coruña \\ Departamento de Humanidades \\ mapr@udc.es \\ [recibido 08/11/2014, aceptado 07/02/2015]
}

\section{RESUMO}

Nesta análise das editoriais O Castro e Cuco-Rei preséntanse as relacións existentes entre elas e co grupo empresarial Sargadelos, así como a liña editorial que seguiron e as correspondencias que tiveron coas editoras do exilio galego en Bos Aires, en especial coas dirixidas por Luís Seoane. O estudo tamén contempla como entre 1963 e 1978 xa adiantan o vieiro que logo caracterizará a Ediciós do Castro, consistente visibilizar o labor da xeración do Seminario de Estudos Galegos e en recuperar a nosa memoria histórica.

PAlABRAs Chave: Ediciós do Castro, Editorial Cuco-Rei, Grupo Sargadelos, memoria histórica, exilio na Arxentina, libros de artista.

\section{RESUMEN}

En este análisis de las editoriales O Castro y Cuco-Rei se presentan las relaciones existentes entre ellas y con el grupo empresarial Sargadelos, así como la línea editorial que siguieron y las correspondencias que tuvieron con las editoras del exilio gallego en Buenos Aires, en especial con las dirigidas por Luís Seoane. El estudio también contempla cómo entre 1963 y 1978 ya adelantan la línea que después caracterizará a Ediciós do Castro, consistente en hacer visible la labor de la generación del Seminario de Estudos Galegos y en recuperar nuestra memoria histórica.

PAlabras Clave: Ediciós do Castro, Editorial Cuco-Rei, Grupo Sargadelos, memoria histórica, exilio en Argentina, libros de artista.

\begin{abstract}
This is an analysis of two publishing companies: O Castro and Cuco-Rei. We shall look at their commercial relationship as well as their dealings with the Sargadelos business group. We shall also examine their editorial line and correspondence with exiled Galician publishers in Buenos Aires, paying particular attention to those led by Seoane. This analysis also shows how O Castro was characterised by its editorial line that began to develop from 1963 to 1978 , and which consisted in showing the work of the Seminario de Estudos Galegos and in recuperating Galician historical memory.
\end{abstract}

KEY wORDS: Ediciós do Castro, Editorial Cuco-Rei, Grupo Sargadelos, historical memory, exile in Argentina, artist books.

PÉRez Rodríguez, Ma A. (2015): “Ediciós do Castro e Editorial Cuco-Rei (1963-1978)”, Madrygal (Madr.), 18, Núm. Especial: 495-508.

SUMARIO: 1. Introdución: grupo empresarial Sargadelos. 2. Fundación e primeiros anos de Ediciós do Castro. 3. Desenvolvemento e principais liñas editoriais. 4. Publicacións de Ediciós do Castro entre 1963-1978. 5. A editorial Cuco-Rei. 6. Editorial de autor. 7. Dous álbums de gravados en madeira de Luís Seoane. 8. Conclusións. 9. Referencias bibliográficas.

* Texto escrito ao abeiro do proxecto de investigación: "La producción editorial en Galicia durante la etapa franquista (1939-1975)" (Ministerio de Educación y Cultura FFI2010-16924). 


\section{INTRODUCIÓN: GRUPO EMPRESA- RIAL SARGADELOS}

As empresas do grupo Sargadelos teñen a súa primeira planificación en Bos Aires. Alí estaba refuxiado Luís Seoane e alí acudiría Isaac Díaz Pardo entre 1955 e 1978 en máis de cinco ocasións, xa que, acollendónse a un plano do goberno arxentino para inversións extranxeiras, instalou en La Magdalena unha fábrica de cerámica na que ensaiou algunhas das fórmulas que logo, adaptadas, desenvolvería na de Galiza.

Sargadelos asenta a súa estratexia comercial na proximidade e calidade da mateira prima (caolíns de Burela, pegmatitas de Silán) nun coidado proceso de fabricación no que subxacen os postulados da Bauhaus (incluso os de Art and Craft), nun deseño que conxuga a instrumentalidade do produto cunha estética baseada na reelaboración das formas máis representativas da cultura galega, as tendencias da escola de Ulm e as da plástica das décadas de 1960-80.

A súa estratexia comercial tamén se basea na distribución controlada pola empresa e nunha imaxe de marca entroncada co pedegree que lle achega estar localizada no lugar onde estivo asentado un dos vellos intentos de industrialización en Galiza (séculos XVIII-XIX) e adoptar o seu mesmo nome. A isto súmase o compromiso de poñer en valor e divulgar a nosa cultura, comezando pola recuperación das nosas formas, xa que, como linguaxe, posúen "...unha orixe, un antecedente, unha nai, unha patria", como tantas e tantas veces repetiría Díaz Pardo ao longo de toda súa vida.

Ediciós do Castro cifra unha das súas metas en atender as necesidades da empresa, e en publicar textos sobre cerámica e o pasado da antiga factoría ${ }^{1}$, así como en dar servizo a todo o proxecto integrado no Laboratorio de Formas de Galicia, constituído en 1965 mediante un convenio. Camilo Díaz Arias recorda que agroma das conversas “...en 1963, a cabalo entre Bos Aires e a Magdalena, o Laboratorio de Formas de Galicia, que sería rexistrado tempo despois no noso país (...) Desde o inicio da actividade en Sargadelos en 1968, Isaac e Seoane levaron a dirección, como estipula o convenio" (VV. AA. 2008: 110). Díaz Pardo precisa que desde as súas orixes xa existía a intención de recuperar a nosa memoria histórica e o labor do Seminario de Estudos Galegos (Díaz Pardo 1978: 7), dous itinerarios imposíbeis de illar, que $\mathrm{O}$ Castro intensificou tras o fanado golpe de estado de 1981, e que mantivo ata a súa desaparición.

\section{FUNDACIÓN E PRIMEIROS ANOS DE EDICIÓS DO CASTRO}

A primeira produción das instalacións de Cervo data de 1968. Son 18 xerras deseñadas por Luís Seoane que "recrean" testas de personaxes galegos "históricos". Pero xa en 1963 comeza a funcionar Ediciós do Castro que, ata 1969, pon na rúa trece publicacións. Delas sete pertencen aos seus fundadores, que posibelmente fosen os impulsores directos de Souto (1969), un pequeno estudo sobre este pintor do movemento renovador refuxiado en México e do que Seoane posteriormente recuperaría e editaría os seus debuxos de guerra.

Son da autoría de Díaz Pardo Cecilia la ácrobata (1965), un álbum de debuxos do que gosta moito Luís Seoane (Díaz Rey 2004: 147), un libro sobre o escultor republicano Barral (1965), para o cal Seoane lle consegue o material en Arxentina, e outro sobre o cuñado deste, o ceramista Arranz. Fernando Arranz foi en Bos Aires responsábel da Escola Nacional de Cerámica, profesor en Belas Artes, traballou para La Magdalena e pasou a cerámica deseños do citado pintor (a vaixela e a lousa dun patio do Centro Lugués, portas de estabelecementos comerciais etc.).

Díaz Pardo escribe o limiar de Retratos de Esguello (1967), que recolle debuxos feitos ás présas por Seoane en cafés e bares; un

\footnotetext{
${ }^{1}$ Entrevista con Xosé Diaz Arias, para a realización do proxecto de investigación antes citado.
} 
ano despois este pon na rúa en Arxentina Retratos Furtivos, como el mesmo di “...irmán maior do que publicou Edicións O Castro" (Fernández del Riego 2002: 160), e redacta o seu limiar, o do álbum de xilografías Historia dun Paxaro (1969) e, antes, o das dúas carpetas coas que $\mathrm{O}$ Castro inicia a súa andaina. González Garcés (1964) sostén: “Aunque no sean propiamente manifestaciones literarias, en parte lo son por sus magníficos prefacios, no podemos dejar de mencionar dos libros que han de ser fundamentales en la historia del libro coruñés". Refírese a El Toro Júbilo e $O$ $M e c o$, álbums que patentizan a intertextualidade de grande parte da obra do seu autor, quen nos limiares consigna con moderación o simbolismo que acadan as lendas que os "inspiran". No de $O$ Meco non nomea as correspondencias entre o xeneral Franco e o cruel e despótico clérigo e señor do Grove axustizado por un pobo farto que colectivamente asume tal responsabilidade. Nas súas cartas tampouco subliña os paralelismos con Fonteovejuna e, sempre coidadoso de canto escribe referido a cuestións políticas, limítase a aludir á peza de Lope de Vega.

Os outros cinco libros publicados ata 1969 contribuen á comprensión da evolución de $\mathrm{O}$ Castro e -por extensón- adiantan os ideoloxemas $^{2}$ nos que asenta a súa liña editorial. O Catón Galego quedara adiado en 1936 cando Ben-Cho-Shey fora represaliado, e valorámolo, xunto con de Máquinas e Trebellos... (1970), como un indicativo do comezo da loita pola galeguización do noso ensino. O libro de
Gómez de la Serna Viaje a Sargadelos narra unha viaxe a Sargadelos e Tomás Barros en Procesos abstractivos del arte contempóraneo analiza a arte non figurativa en xeral. A reedición de $O$ divino sainete cabe interpretala como a recuperación dun texto con ligazóns co ideario da poesía social de 1950-70 e dun escritor silenciado. En 1967 adicáraselle a Curros o día das Letras Galegas e en 1969 cumprírase o oitenta aniversario da saída de $O$ Divino Sainete. A edición de O Castro pertence a Alonso Montero ${ }^{3}$ e está ilustrada por nove artistas, feito que desaproba Seoane, autor da capa, xa que pensa que un só “...debe responsabilizarse ante la obra que se le ofrece (...) Si no cambian de criterio pronto los libros gallegos se parecerán a los álbumes de las señoras que recogen autógrafos" (Diaz Rey 2004: 253).

Entre 1963 e 1978 producíronse en Ediciós do Castro, alén dos libros, os Cadernos do Laboratorio de Formas de Galicia, os Cuadernos del Seminario de Estudios Cerámicos de Sargadelos e as Publicacións do Museo Carlos Maside. Os primeiros céntranse no estudo das formas da plástica galega, en explicar a conceptualización e a orientación das factorías e os organismos culturais que promoven, así como en recoller algunhas das actividades do grupo (inauguración das galerías Sargadelos en Barcelona e Madrid, primeiro seminario sobre o libro Galego ${ }^{4}$ etc.). Ata 1978 saen cinco cadernos, todos con deseño de Seoane; para distinguilos varía a cor das capas, pero sempre empregando nelas as letras LF reelaborándoas, un recurso que non sorprende se tomamos en

\footnotetext{
${ }^{2}$ Bajtín considera o signo lingüístico “ideolóxico” e, por tanto, “dialóxico”. Para el o ideoloxema traduce un sistema de valores en consonancia co "horizonte de expectativas"; e expresa un concepto acaído para nomear expresións que aparecen no texto con marcas estilísticas ou conceptuais relacionadas con círculos sociais ou coa ideoloxía que desprenden (Bajtín 1992 e 1994).

${ }^{3}$ Tamén conta cun ensaio do teólogo Andrés Torres Queiruga, entón residente en Roma. Alonso Montero publicou en 1969, en ed. Alborada, O que compre saber da linga Galega, con capa de Seoane.

4 Tivo lugar nos primeiros días de xullo de 1972 no museo Carlos Maside. Nel debateuse bastante a proposta de Rafael Dieste de crear en Galiza unha editorial que atendese as culturas galega, castelá e portuguesa e que distribuíse a súa produción neses mercados. Era un asunto que entón se pensou en realizar se o Faro de Vigo optaba por abrir unha división editorial, tal como estaba a valorar. Ao seminario asistiron intelectuais con experiencia na comercialización do libro como Manuel María, Ramón Piñeiro, Blanco Amor ou Alexandre Finisterre.
} 
consideración a pegada que exerceron sobre a súa plástica os códices medievais, así como o feito de que en EMECE fora compañeiro do austríaco Jacobo Hermelin, un dos renovadores da caligrafía na Arxentina, "arte" que alí se aprendía no ensino ata hai uns cuarenta anos.

Os Cuadernos do Seminario de Estudios Cerámicos de Sargadelos basicamente versan sobre os resultados da escola de verán que tiña lugar en Cervo desde 1972, sobre escultores que empregaban a arxila e que participan neses cursos (como Arcadio Blasco ou Silverio Rivas); sobre a catalogación e clasificación da cerámica popular, prehistórica e da idade antiga, ou sobre as técnicas de elaboración e diferentes usos e estilos das pezas de barro. Todos os Cuadernos contan con abundantes fotografías e son da autoría de estudosos ben coñecedores do devir da factoría (caso de Filgueira Valverde) ou de especialistas nos temas tratados nesas aulas, impartidas nos meses de xullo e agosto, como Castro Arines, Guitián Ojea, Xosé Díaz Arias, Vázquez Varela, Chávarri, Natacha Seseña, Blanco Freijeiro, F. A. Calvo, Inés Canosa, Sala, Shaw ou Andrés Varela. No no 29 (1979) Meijide Pardo dá a coñecer os documentos que Seoane mercou na Arxentina aos herdeiros das antigas fábricas, entre eles a Real Célula de 1791 autorizando a fundición.

As Publicacións do Museo Carlos Maside non son os catálogos das súas mostras, senón que recollen conferencias ou intervención en actos que se celebraron nel con motivo dalgunha das exposicións ou conmemoracións. Neles asinan Enrique Azcoaga, Castro Arines, Corredor Matheos, García Sabell, Bonet Correa ou Seoane, que escribe sobre o seu admirado George Grosz e deseña esos libriños co seu característico cromatismo das capas.

\section{DESENVOLVEMENTO E PRINCI- PAIS LIÑAS EDITORIAIS}

No resto das publicacións de O Castro atopamos a autores canónicos, xunto a outros, antes de 1936, integrantes ou colaboradores do Seminario de Estudos Galegos ou con presenza na Editorial Nos; a exiliados, a antifranquistas asentados na Península; a creadores nos comezos da súa produción ou iniciando a entrada no eido editoral, e a outros que escriben sobre Sargadelos como Gaspar Gómez de la Serna, Bello Piñeiro, Filgueira Valverde ou Vilar Checa, esta última cunha monografía con capa de Seoane inspirada nas insculturas neolíticas. As edicións bilingües son relativamente frecuentes e os libros vertidos ao galego limítanse a catro: o de Cuns de $O$ carteiro do rei de Tagore (curiosamente un poema de Tagore figura na revista Resol $^{5}$ e Correa Calderón ${ }^{6}$ ten pegada deste escritor hindú nas súas concepcións pedagóxicas), dúas traducións realizadas por Neira Vilas de candanseu poemario de Nicolás Guillén e de Ho-Chi-Ming, e outra feita por Basilio Losada de poemas en catalán de Jordi Domenech.

Entre os autores canónicos encóntranse Castelao, Curros, Cabanillas e Pondal; deste último Seoane e Cuadrado xa editaran en EMECE Queixumes dos pinos (1940). Do Seminario de Estudos Galegos aparece Cotarelo Valledor coa separata que tirara Ánxel Casal do seu capítulo en Terra de Melide (1933), tratado esgotado en 1978 e que ve a luz por segunda vez en O Castro en edición facsimilar presentada nun ateigado e emotivo acto $^{7}$ celebrado no Museo do Pobo Galego. Sinalamos que Celso Emilio Ferreiro (1978b: 31) lle adicou a Terra de Melide un eloxioso comentario no apartado da sección de crítica literaria da cal se encargaba en $\mathrm{ABC}$ e na que se ocupa

\footnotetext{
${ }^{5}$ No no 8 (xullo de 1933).

${ }^{6}$ A pegada é manifesta en "Notas para un maxisterio idealista", texto publicado na revista Vida Escolar e como separata en 1927, baixo o auspicio das Irmandades da Fala.

${ }^{7}$ Faise coincidir coa inauguración do local de Cerámicas Sargadelos en Santiago e coa exposición Homenaxe ao Seminario de Estudos Galegos que ten lugar nel. O Caderno do Laboratorio de Formas de Galicia $\mathrm{n}^{\circ}$ 5, de 1978, titulado Testimuñas e Perspectivas, é unha homenaxe ao Seminario.
} 
en varias ocasións dos libros de O Castro. Outros integrantes ou vencellados ao Seminario de Estudos Galegos presentes en O Castro son Francisco Lanza (con dúas monografías), Castro Arines, Carré Alvarellos (con $\mathrm{Os} \mathrm{Pi-}$ coutos de Antoín, premiado en 1929 no Centro Galego de Montevideo e en 1955 editado en Braga), Ben-Cho-Shey ou Parga Pondal, este último cun caderno na súa honra editado após o seu falecemento.

Entre os autores exiliados encontramos a Dieste ${ }^{8}$ con varios prólogos, Testamento Geométrico, e o seu discurso de entrada na Real Academia Galega xunto coa resposta de García-Sabell; a González López, que xa publicara estudos sobre a historia de Galiza nas edicións do Centro Galego de Bos Aires, ou a Emilio Pita co facsímile de Jacobusland ilustrado por Castelao en 1942. Este dorido poemario de denuncia, antecedente do noso social-realismo poético, non se chegou a publicar en EMECE cando a levaban Cuadrado e Seoane, quen lle publicou a Pita Os relembros. As cantigas na editorial Citania (1959) e animou a Fernandez del Riego para que fixese o mesmo con Ronsel Verdegal (col. Salnés, 1964).

Eduardo Blanco-Amor e Xosé Neira Vilas, en puridade, son republicanos galeguistas asentados en Bos Aires, non refuxiados. O primeiro editou en Citania, con ilustración de Seoane, A Esmorga (1959), e agora en O Castro Farsas para títeres. Nesta categoría situamos ao entón prestixioso crítico de arte Enrique Azcoaga, cun libro en Ed. Botella al Mar e moi amigo de Blanco Amor, Rafael Dieste, Lorenzo Varela, e, moi en especial, de Maruja Mallo.

Neira Vilas foi quen aconsella a Galaxia que poña na rúa libros para rapaces ${ }^{9}$. Porén, Memorias dun neno Labrego (1968), que aparecera en Follas Novas de Bos Aires en 1961 con capa de Seoane, abre a porta á literatura infantil e xuvenil en Ediciós do Castro. Neira
Vilas xa fixera amizade na Arxentina cos dous donos desta editorial, de aí que non estrañe que lle adicase a Isaac Díaz Pardo e a Carme Arias Historias de Emigrantes, (1968), tamén con capa de Seoane, que tirou en Montevideo o Padroado da Cultura Galega e que reedita O Castro en 1975. Ademais dos autores xa mencionados, figuran con pezas de literatura infantil e xuvenil en O Castro Neira Vilas, de novo, con Cartas a Lelo e Cabaliño de buxo, Abeixón, Moreno Márquez, Lueiro ou Ramiro Cartelle.

Canto a Martínez-Risco Macías, Parga Pondal e Paz Andrade, afincados na península, figuran no catálogo da editorial Citania con obras non literarias. Do último, O Castro tira a terceira edición de Pranto Matricial no 25 cabodano de Castelao, a quen estaba adicado. Respecta a edición bonaerense de Ed. Galicia (1955), esta con capa de Seoane, versión castelá de María Villarino e ilustracións de Colmeiro, Maside, Torres e Souto; no entanto, engádelle un limiar de Dieste e as traducións ao portugués (Guillerme de Almeida), ao euskera (Gabriel Aresti) e ao catalán (Francec Valverde).

Lueiro Rey en O Castro publica en 1974 Escolma Ferida, na que recolle poemas xa editados en revistas e na prensa, e nela intégrase un limiar de Lorenzo Varela, un poeta cunha poética coa cal el presenta bastantes concomitancias. Lueiro xa editara La Noche espera al alba (1971) en Ed. Botella al Mar con capas de Seoane, quen así mesmo lle realizara as cubertas doutros dous libros para a editorial porteña Oberón ${ }^{10}$ (1968). Celso Emilio Ferreiro en ABC (1978a: 33) gababa a Escolma Ferida coa precaución requerida nesa década, algo entendíbel ao ser considerada dentro da denominada "poesía social".

Son tamén susceptíbeis de encadrar nese movemento Un poema en dez anacos de Jordi Domenech (1974) e Anos de vougo de Xavier

\footnotetext{
${ }^{8}$ Cómpre non esquecer o rol tan importante que desempeñou Dieste no grupo Sargadelos.

${ }^{9}$ Entrevista con Xosé Neira Vilas para a realización do proxecto de investigación antes citado.

${ }^{10}$ Son as narracións Manso, en España censurada na edición de 1967, e Vicente y el otro.
} 
Costa Clavell (1977), que se publica coa advertencia de que algúns poemas son anteriores a 1970; este libro sae en O Castro despois de que non o publicara o Padroado da Cultura Galega de Montevideo, institución á que, xunto con outros libros, llo ofrece Carlos Díaz ${ }^{11}$ en 1974. Díaz era o encargado en Xenebra da colección O Rego e das edicións Roi Xordo ${ }^{12}$ (pertencían á UPG), que só editou algún dos poemarios que o seu responsábel ofertara a esa entidade nacionalista galega en Sudamérica. Porén, en 1973, Roi Xordo editou A cova das cholas (revista de comic galego $n^{\circ} 1$ ), toda ela debuxada polo Grupo do Castro constituído por Xosé Díaz e Xesús Campos (Chichi), unha banda deseñada que se destribúe en Galiza clandestinamente, como o resto das publicacións de Roi Xordo. Ainda así, fora todo un "éxito comercial".

Desde 1977 O Castro publica os relatos curtos galardoados co premio Modesto Rodríguez Figueiredo; porén, a novela ou o conto non foron subxéneros aos que a editora lles concedese primacía, malia que visibilizou a narradores daquela con só relativa ou nula presenza no noso campo cultural, como Fernandez Ferreiro ou $\mathrm{M}^{\mathrm{a}}$ Xosé Queizán, ou postumamente a Xohan Casal; os três curiosamente con ligazóns co grupo "Brais Pinto". A morte de Frank González remítenos ao oeste norteamericano e á prosa de Hemingway; ademais, a súa capa volve enlazar o relato con América, xa que a testa do vaqueiro que para ela debuxou Seoane lembra as ilustacións deste para Martín Fierro ou 32 refráns criollos. Neste punto, convén subliñar que sobre a trama da outra novela que publica Ferreiro en O Castro incide a loita dos labregos contra o asulagamento das terras para construír o encoro de Castrelo de Miño, unha cuestión "tabú" aínda en 1978, pero que non arredou a O Castro na escolla dunha capa de Xosé Díaz cunha lectura moi dura para cos poderes económicos e políticos. Por outra banda, o ensaio feminista en Galiza ten en A muller en Galicia. A Muller na sociedade galega un dos seus primeiros contributos, xa que $\mathrm{M}^{\mathrm{a}}$ Xosé Queizán ${ }^{13}$ analiza como a lingua é arma e ao tempo expoñente da explotación da muller.

Logo, a editora relegou a liña editorial que poderiamos denominar como "feminista" e bastante a da literatura infantil. Chama a atención porque as mulleres eran as destinatarias principais dos produtos do grupo Sargadelos, e porque un dos seus obxectivos consistía en lograr publicidade de calidade con incidencia nas emerxentes clases medias, principais clientes das cerámicas, e entre elas xermolaba o movemento feminista galego. Unha das explicacións quizais radique na morte de Seoane en 1969; non esquezamos que o seu labor no grupo Sargadelos se inscribe dentro do macrotexto que constitúe o conxunto da súa produción, e que usou a muller coma recurso plástico-conceptual e converteu a súa imaxe nun símbolo e nun axente semiótico con capacidade para contribuír a propiciar o cambio social.

O Castro tampouco se preocupou de manter unha colección de poesía. Porén, a poesía motiva que en 1978 os seus dous responsábeis polemice con César Antonio Molina cando este arremete contra a Antoloxía da poesía galega actual. Molina (1978: s. p.) opina como se nela se escolmase o mellor de cada poeta- cando na nota do comezo do libro o grupo Nordés especifica que non é así. Xúlgaa mal por non incluír a Lorenzo Varela, Tovar, Cuña Novás ou López Casanova, e só salva a Cunqueiro, Bernardino Graña, Novoneira, Méndez Ferrín e Celso Emilio Ferreiro. Díaz Pardo replícalle defendendo a dita antoloxía e a Seoane, pero non a Paz Andrade, contra o que Molina ataca especialmente. Isaac di:

\footnotetext{
${ }^{11}$ Carta conservada no arquivo da Unión do Pobo Galego (sección internacional-Suíza).

${ }^{12}$ Lembremos a vinculación que mantiveron Seoane e Camilo Díaz co partido político dono de Ed. Roi Xordo.

${ }^{13}$ A finais de 1970 Seoane expón na Galería Roizara de Vigo, que dirixía esta escritora e Carmela Arbones.
} 
Sorprende que al ocuparse de algo de Galicia, La Calle en el $n^{\circ} 10$ que lo haga para recoger un ataque contra una Antología de Poesía Gallega del grupo Nordés, como si en Galicia no hubiese problemas angustiosos con los que se podrían hacer magníficas crónicas periodísticas (...) Sin salirnos de las palabras con que el crítico rechaza lo que hace Seoane como poeta (...) estas mismas palabras nos valen a muchos para fijar las condiciones que ha de tener la poética de nuestro tiempo, porque la entendemos más como una crónica profunda del drama y de la esperanza de nuestra existencia que como fantasía hija de nuestros ocios (...) y porque mientras estos poetas hacían esto, otros hombres se dedicaban en la prensa gallega a ocultar la realidad de los gallegos llenando sus páginas de literatura castellana para hacernos creer que todo iba bien. Díaz Pardo (1978b: s. p.)

Seoane autor da capa da antoloxia, contéstalle a Antonio Molina, malia que por carta lle di a Fernández del Riego (2002: 171) que coida que o, para el, descoñecido crítico non desexaba quedar mal con el. E na resposta omite o primeiro dos nomes do futuro ministro de cultura, co cal o fai coincidir co dun entón popular cantante de copla española, e matiza

...remata un sen saber o que é a poesía, atopándoa, no meu caso, en vellos cronicóns históricos, en noticias de xornais e no coñecemento de feitos reais que parecen inverosímiles. Esto ocorreume. Nos anos que seguiron a guerra eran as noticias dos xornais as que me daban un mundo poético inédito no noso idioma que xurdía de sucesos que pasaban por outo a maioria dos lectores. A miña experiencia acrecentouse nos meus anos de xornalista en Bos Aires. Nin o suceso era alleo á poesía en calquera dos seus xéneros e moitos estaban expresados poeticamente ca mesma prosa descoidada, urxente do xornalista que o describía. Por iso admito incluso que digan que a miña poesía é máis ben un alegato. É verdade (...) Estou máis preto de Allen Guinsberg (sic), do seu poema Kaddish (1959) e da maioria dos poetas que xuntou a revista mexicana "El Cuerno emplumado" de mediados dos sesenta, con colaboracións de Estado Unidos e Latinoamérica, que de moitos da miña xeneración en calquer parte, demasiados preocupados por cuestións formales que non me interesan en poesía como tampouco en pintura. (Seoane 1978: s. p.)

\section{PUBLICACIÓNS DE EDICIÓNS DO CASTRO ENTRE 1963-1978}

En O Castro, en dazaseis anos, contabilizamos 102 publicacións entre as que 13 son carpetas-álbums, das cales cinco son de debuxo: de Seoane (3), Díaz Pardo (1) e García Súarez (1). De xilografias de Seoane hai catro, o mesmo que acontece coas carpetas-cartaces de cego de Díaz Pardo; destes, dous posúen texto seu e música de Cartelle, noutro escribe tamén el pero carece de música, e o cuarto presenta un texto de Celso Emilio e música de Maiztegui. Nestes cartaces Isaac bota man dun xeito de expresión popular no que se funde debuxo, canción e narración, e que acadou grande difusión en Galiza ata finais de 1940, que empregou Seoane entre 1937 e 1946, e que Isaac moderniza imprimíndolle algúns toques da estética da banda deseñada.

A catalogación cronolóxica das publicacións de edicións de $\mathrm{O}$ Castro que aparece a continuación permite constatar que na súa primeira etapa xa adianta o viero que seguirá a partir de 1982. Nela non figuran os 28 Cuadernos del Seminario de Estudios Cerámicos de Sargadelos nin os pequenos "catálogos" que tirou con motivo dalgunha das mostras no Museo Carlos Maside de Sada ou en entidades, públicas ou privadas, coas que mantiña algún tipo de relación.

\section{3}

Seoane, Luís. El Toro Júbilo. Sada: Ediciós do Castro, 1963, 10 pp., $41 \mathrm{~cm}$.

Seoane, Luís. O Meco. Sada: Ediciós do Castro, 1963, 16 pp.

\section{4}

Díaz Pardo, Isaac. El ceramista Arranz y su escuela. Sada: Ediciós do Castro, 1964, 45 pp., 17 cm.

\section{5}

Díaz Pardo, Isaac. El escultor Emiliano Barral. Sada: Ediciós do Castro, 1965, 42 pp., $17 \mathrm{~cm}$.

Díaz Pardo, Isaac. 20 desnudos de Cecilia la Acróbata. Sada: Ediciós do Castro, 1965, 40 pp., $27 \mathrm{~cm}$.

\section{7}

Barros, Tomás. Procesos abstractivos del arte contempóraneo. Sada: Ediciós do Castro, 1967, 85 pp., $24 \mathrm{~cm}$. 
Gómez de la Serna, Gaspar. Viaje a Sargadelos. Sada: Ediciós do Castro, 1967, 96 pp., 17 cm.

\section{8}

Neira Vilas, Xosé. Memorias dun neno labrego. Sada: Ediciós do Castro (narrativa), 1968, 123 pp., 19 cm. Limiar Alonso Montero. Capa Seoane. Ilustracións Díaz Pardo.

Seoane, Luís. Retratos desguello. Sada: Ediciós do Castro, 1968, 40 pp., 19 cm. Limiar Díaz Pardo.

\section{9}

Curros Enríquez, Manuel. O Divino sainete. Sada: Ediciós do Castro (poesía), 1969, 180 pp., $19 \mathrm{~cm}$. Limiar e notas Alonso Montero. Capa Seoane

Dieste, Rafael (ed.). O pintor Arturo Souto. Sada: Ediciós do Castro (Publicacións do Museo Carlos Maside), 1969, 42 pp., $17 \mathrm{~cm}$.

Fernández Oxea, Xosé Ramón (Ben-Cho-Shey). Catón galego. Sada: Ediciós do Castro, 1969, 145 pp., 24 cm. Limiar Alonso Montero. Capa Seoane.

Seoane, Luís. Homaxe a un paxaro. Sada: Ediciós do Castro 1969, xilografías.

\section{0}

Abad Flores, Odón Luis. Máquinas e trebellos pra labrar a terra. Complemento agrícola ó Catón Galego. Sada: Ediciós do Castro (narrativa), 1970, 32 pp., 24 cm. Capa Xose Díaz.

Cartel de Cego. A nave espacial. Historia contada polo cego Zago. Sada: Ediciós do Castro, 1970, 4 pp., pleg. $33 \mathrm{~cm}$. Música Ramiro Cartelle. Ilustracións Díaz Pardo.

Cartel de Cego. O Marqués de Sargadelos. Historia contada polo cego Zago. Sada: Ediciós do Castro, 1970, 14 pp., 33 cm. Música Ramiro Cartelle. Ilustracións Díaz Pardo.

Casado Nieto, Manuel. 0,1,2,3,4... Trancos da vida do Braisiño. Sada: Edicións do Castro (narrativa), 1970, 120 pp., 20 cm. Capa Seoane.

Casal, Xohán. O Camiño de abaixo. Sada: Ediciós do Castro (narrativa), 1970, 131 pp., 19 cm. Limiar Reimundo Patiño. Capa Seoane.

Castelao, Alfonso R. Dous contos, cinco "Cousas" e mais un debuxo inédito. Sada: Ediciós do Castro, 1970, 32 pp., 19 cm. Limiar Alonso Montero.

Díaz Pardo, Isaac e Seoane, Luís. Cuaderno do Laboratorio de Formas de Galicia $n^{\circ} 1$. Sada: Edicións do Castro, 1970, 23 pp., 24 cm.
Cartel de Cego. Paco Pixiñas. Historia dun desleigado contada por el mesmo. Sada: Edicións do Castro, 1970, 15 pp., pleg. $33 \mathrm{~cm}$. Música Isidro B. Maiztegui. Epílogo Celso Emilio Ferreiro. Ilustracións Díaz Pardo.

Alonso Montero, Xesús; Ramos de Castro, Epifanio e Palmás, Ricardo (eds). Castelao na voz dos poetas. Aportaciós pra unha bibliografía de Castelao. Sada: Ediciós do Castro, 1970, $113 \mathrm{pp} ., 18 \mathrm{~cm}$.

Vilar Checa, Eloisa. El Marqués de Sargadelos y su obra. Sada: Edicións do Castro, 1970, 198 pp., $24 \mathrm{~cm}$. Capa Seoane

\section{1}

Abeixón, Guillermo, Choio e o rei Talento (A Coruña): Ediciós do Castro (narrativa para nenos), 1971, 14 pp., 19 cm. Capa Xosé Díaz.

Dieste, Rafael. A vontade de estilo na fala popular. Sada: Ediciós do Castro, 1971, 56 pp., $24 \mathrm{~cm}$.

García-Sabell, Domingo. A pintura como comunicación. Sada: Ediciós do Castro (Publicacións do Museo Carlos Maside), 1971, 78 pp., $20 \mathrm{~cm}$.

Neira Vilas, Xosé. O Cabaliño de buxo. Sada: Ediciós do Castro, 1971, 68 pp., $20 \mathrm{~cm}$.

\section{2}

Castro Arines, José de. El arte del grabado a propósito de Antonio Clavé. Sada: Ediciós do Castro (Publicacións do Museo Carlos Maside), 1972, 49 pp.,, $19 \mathrm{~cm}$.

Catálogo da $1^{a}$ Mostra do libro galego en Cataluña. Galería Sargadelos. Sada: Ediciós do Castro, 1972, 51 pp., $20 \mathrm{~cm}$. Capa Seoane.

Corredor Matheos, José. Dos conferencias sobre cerámica: requiem por la cerámica popular española. La cerámica de Miró-Artigas. Sada Ediciós do Castro (Publicacións do Museo Carlos Maside), 1972, 48 pp., $19 \mathrm{~cm}$.

González Martín, Jerónimo Pablo. Ensayo sobre la poesía gallega contemporánea. Sada: Ediciós do Castro, 1972, 156 pp., $18 \mathrm{~cm}$.

Pita, Emilio. Jacobusland. Sada: Ediciós do Castro (poesía), 1972, 97 pp., 19 cm. Limiar Alonso Montero.

VV.AA. Tradición e futuro. Sada: Ediciós do Castro, 1972, 28 pp., $22 \mathrm{~cm}$.

\section{3}

Blanco-Amor, Eduardo. Farsas para títeres. Sada: Ediciós do Castro (teatro), 1973, 280 pp., 19 $\mathrm{cm}$. Capa Seoane. 
Lanza Álvarez, Francisco. Ribadeo Antigo. Sada: Ediciós do Castro, 1974, 356 pp., $17 \mathrm{~cm}$.

Martínez Risco, Sebastián. 14 Nadaliñas: 19581973. Sada: Ediciós do Castro (poesía), 1973, 24 pp., $19 \mathrm{~cm}$.

Martínez Risco, Sebastián. Presencia da lingua galega. Sada: Ediciós do Castro, 1973, 46 pp. $24 \mathrm{~cm}$.

Moreno Márquez, María Victoria. Mar adiante: Historias de nenos pra nenos. Sada: Ediciós do Castro, 1973, 62 pp., 24 cm. Capa Carmen Arias.

Seoane, Luís. Un feixe de dibuxos case esquecidos. Sada: Ediciós do Castro, 1973, 41 pp., $32 \mathrm{~cm}$. Limiar Díaz Pardo

\section{4}

Bonet Correa, Antonio. El significado del arte en nuestro tiempo. Sada: Ediciós do Castro (Publicaciones del Museo Carlos Maside), 1974, 39 pp., $20 \mathrm{~cm}$.

Domenech, Jordi. Un poema en dez anacos. Sada: Ediciós do Castro 1974, 33 pp., $19 \mathrm{~cm}$. Tradución Basilio Losada.

Lanza Álvarez, Francisco. Falan os de Ribadeo. $O$ ensino en Ribadeo dende o século XVI ó XIX. Sada: Ediciós do Castro, 1974, 147 pp., 17 cm. Limiar e notas Eduardo Gutíerrez.

Lueiro Rey, Manuel. Non debian medrar. Sada: Ediciós do Castro (narrativa), 1974, 97 pp., 20 $\mathrm{cm}$. Capa Seoane.

Mon Rodríguez, Fernando. Del ayer histórico a la joven pintura gallega. Sada: Ediciós do Castro (Publicaciones del Museo Carlos Maside), 1974, 28 pp., $20 \mathrm{~cm}$.

O Libro galego a discusión. Seminario encol do Libro Galego. Sada: Ediciós do Castro (Cadernos do Laboratorio de Formas de Galicia $\mathrm{n}^{\circ} 2$ ), 1974, 95 pp., $24 \mathrm{~cm}$.

Villaverde, Luis. Mariscos de Galicia. Sada: Ediciós do Castro, 1974, 260 pp., $17 \mathrm{~cm}$. Notas Paz-Andrade.

\section{5}

Carré Alvarellos, Leandro. Nos picoutos de Antoín. Sada: Ediciós do Castro (narrativa), 1975, 90 pp., $19 \mathrm{~cm}$. Capa Xose Díaz.

Castro Arines, José de. O Libro das Galerías Galegas. Sada: Ediciós do Castro, 1975, 77 pp., $21 \mathrm{~cm}$.

Díaz, Xosé. O escultor Alberto. Sada: Ediciós do Castro, 1975, 60 pp., $19 \mathrm{~cm}$.
Dieste, Rafael. Testamento geométrico. Sada: Ediciós do Castro, 1975, 145 pp., $19 \mathrm{~cm}$.

Fernández Ferreiro, Xosé. A Morte de Frank González. Sada: Ediciós do Castro, 1975, 91 pp., 20 $\mathrm{cm}$. Capa Seoane.

Fernández Ferreiro, Xosé. Morrer en Castrelo do Miño. Sada: Ediciós do Castro, 1978, 79 pp., 19 $\mathrm{cm}$. Capa Xosé Diaz.

García Suarez, Ricardo (Xohan Ledo). Indix, Indicente. Sada: Ediciós do Castro, 1975, 59 pp., $24 \mathrm{~cm}$.

Inauguración da Galería Sargadelos en Madrid. Sada: Ediciós do Castro (Cadernos do Laboratorio de Formas de Galicia n ${ }^{\circ}$ 4), 1975, 180 pp., $24 \mathrm{~cm}$.

Neira Vilas, Xosé. Historias de emigrantes. Sada: Ediciós do Castro, 1975, 106 pp., 19 cm. Capa Seoane.

Paz-Andrade, Valentín. Pranto matricial. Sada: Ediciós do Castro (poesía), 1975, 98 pp., 19 $\mathrm{cm}$. Capa Xosé Díaz.

Presencia de Galicia. Sada: Ediciós do Castro (Cadernos do Laboratorio de Formas de Galicia $\mathrm{n}^{\circ}$ 3), 1975, 52 pp., $24 \mathrm{~cm}$.

Seoane, Luís. George Grosz. Sada: Ediciós do Castro (Publicacións do museo Carlos Maside), 1975, 65 pp., $17 \mathrm{~cm}$.

Seoane, Luís. Ramallos, caracolas e outros debuxos. Sada: Ediciós do Castro, 1975, 33 pp., $38 \mathrm{~cm}$. Limiar García Sabell.

\section{6}

Cabanillas, Ramón. 6 poemas de Ramón Cabanillas como presencia de Ediciós do Castro no Día das Letras Galegas, 17 de maio. Sada: Ediciós do Castro (poesía), 1976, 14 pp., $17 \mathrm{~cm}$.

Chao Ledo, José M ${ }^{\text {a }}$. Poemas galegos. Sada: Ediciós do Castro, 1976, 97 pp. Limiar García Mato.

Costa Gómez, Xosé $\mathrm{M}^{\mathrm{a}}$. Cas redes cheas. Sada: Ediciós do Castro (poesía), 1976, 37 pp., 19 $\mathrm{cm}$.

González Garcés, Miguel. Poesía gallega de posguerra. Sada: Ediciós do Castro, 1976, 565 pp. (t. 1), 373 pp. (t. 2), $20 \mathrm{~cm}$. Limiar Varela Jácome.

Moreiras Collazo, Eduardo. Fogo solto. Sada: Edicións do Castro, 1976, 179 pp., $19 \mathrm{~cm}$.

Tagore, Rabindranath. $O$ carteiro do rei. Malini. Sada: Ediciós do Castro, 1976, 71 pp., 19 $\mathrm{cm}$. Tradución Xulio Cuns Lousa. Capa Xosé Díaz. 


\section{7}

Cartelle, Ramiro. Coma nós. Sada: Ediciós do Castro (narrativa para nenos), 1977, $34 \mathrm{pp} ., 19 \mathrm{~cm}$. Limiar Alonso Montero

Durán, Carlos; Martínez Oca, Xosé Luis; Méndez Ferrín, Xosé Luís; Taibo, Xosé Ignacio. Catro narracións. Concurso de narracións curtas Modesto R. Figueiredo do Pedrón de Ouro ( $1^{\circ}$. 1976). Sada: Ediciós do Castro, 1977, 87 pp., $19 \mathrm{~cm}$.

Costa Calvell, Xavier. Os Anos do vougo e outros poemas. Sada: Ediciós do Castro, 1977, 71 pp., $19 \mathrm{~cm}$.

Cotarelo Valledor, Armando. Lembranza biográfica de D. Mateo Segade Bugueiro (1605-1672) arcebispo de México, obispo de Cartaxena e... Sada: Ediciós do Castro, 1978, 169 pp., 24 cm.

Fernández Oxea, Xosé. Galicia no corazón. Sada: Ediciós do Castro (ensaio), 1977, 236 pp., 19 $\mathrm{cm}$. Escolma e arranxos Alonso Montero. Limiar Alonso Estravís. Ilustracións Díaz Pardo, Patiño e Seoane. Capa Seoane.

González López, Emilio. Bajo las luces de la Ilustración. Sada: Ediciós do Castro, 1977, 592 pp., $24 \mathrm{~cm}$.

González Martín, Jerónimo Pablo. Cartafol: Homenaxe ós poetas galegos. Sada: Ediciós do Castro, 1977, 44 pp., $33 \mathrm{~cm}$.

Guillén, Nicolás. Trintenove poemas de Nicolás Guillén. Sada: Ediciós do Castro, 1977, 127 pp., $19 \mathrm{~cm}$. Escolma, limiar, notas e tradución Neira Vilas.

Lucas, María. Visión de Galicia en Neira Vilas. Sada: Ediciós do Castro, 1977, 126 pp. Capa Díaz Pardo.

Lueiro Rey, Manuel. Escolma ferida. Sada: Ediciós do Castro (poesía), 1977, 88 pp., $19 \mathrm{~cm}$. Limiar Lorenzo Varela.

O crimen de Londres: a criada que estrangulou a sua ama pola música, historia contada polo Cego Zago en 1970. Sada: Ediciós do Castro, 1977, 16 pp. Debuxos Díaz Pardo

Queizán, María Xosé. A Muller en Galicia. A muller na sociedade galega. A lingua galega e a muller (Análise estructural de dous métodos represivos). Sada: Ediciós do Castro, 1977, 99 pp., $19 \mathrm{~cm}$.

Sarry, Ulises. Tarot Sarry: cartas pra botar. Sada: Edicións do Castro, 1977, 72 pp., 16 cm. Limiar Cunqueiro.

Seoane, Luís. Obra poética. Sada: Ediciós do Castro, 1977, 184 pp., 19 cm. Limiar Basilio Losada.
Seoane, Luís. Imaxes celtas-Grabados en madeira. Sada: Ediciós do Castro, 1977, 26 pp., $26 \mathrm{~cm}$.

Souto, Arturo. Dibuxos da guerra. Sada: Ediciós do Castro, 1977, 20 pp., 27 cm. Limiar Seoane.

Sucarrat Boutet, Francine. Luis Seoane, su obra poética y su importancia en la literatura gallega actual. Sada: Ediciós do Castro (ensaio), 1977, 200 pp., $19 \mathrm{~cm}$.

\section{8}

Barros, Tomás. Abraio. A Coruña : Ediciós do Castro, 1978, 137 pp., 19 cm. Limiar Salvador Lorenzana. Capa Díaz Pardo.

Cortezón, Daniel. Os Irmandiños. Sada: Ediciós do Castro (teatro), 1978., 95 pp., $19 \mathrm{~cm}$.

Discursos parlamentarios 1931-1933. Sada: Ediciós do Castro, 1978, 407 pp. , $19 \mathrm{~cm}$. Limiar Xosé Lois García. Discursos: Castelao, Súarez Picallo, Otero Pedrayo e Villar Ponte.

Durán, Carlos. Galegos de Londres. Sada: Ediciós do Castro, 1978, 163 pp., $19 \mathrm{~cm}$.

A Fundición e outras Narraciíns. Concurso de narracións curtas Modesto R. Figueredo do Pedrón de Ouro (2. 1977). Sada: Ediciós do Castro, 1978, 104 pp., 19 cm. Narradores: Alcalá, Martínez Oca, Rodríguez Barrio, Taibo et al.

García Fernández, Xosé Lois. Do Faro ó Miño. Sada: Ediciós do Castro (poesía), 1978, 95 pp., $19 \mathrm{~cm}$.

González López, Emilio. El Alba flor de lis. Galicia en los reinados de Felipe V, Luis I y Fernando VI. Sada: Ediciós do Castro, 1978, 462 pp., $24 \mathrm{~cm}$.

Ho-Chi-Minh. Xornal de prisión. Sada: Ediciós do Castro (poesía), 1978, 116 pp., $19 \mathrm{~cm}$. Limiar, notas e tradución Neira Vilas.

Neira Vilas, Xosé. Cartas a Lelo. Sada: Ediciós do Castro, 1971. 119 pp., 20 cm. Capa Seoane.

Nordés. Antoloxía da poesía galega actual. Sada: Ediciós do Castro, 1978, 343 pp., $19 \mathrm{~cm}$. Capa Seoane.

Palmás, Ricardo. A emigración galega na Arxentina. Sada: Ediciós do Castro, 1978, 49 pp., 19 $\mathrm{cm}$.

Paz-Andrade, Valentín. A Galecidade na obra de Guimaraes Rosa. Sada: Ediciós do Castro, 1978, 230 pp., 19 cm. Limiar Paulo Ronai. O epílogo recolle a resposta de Cunqueiro a este discurso de entrada na RAG.

Terra de Melide. Sada: Edicións do Castro, 1978, 736 pp., 24 cm. Limiar Filgueira Valverde. 
Testemuñas e perspectivas en homenaxe ao Seminario de Estudos Galegos. Sada: Edicións do Castro (Cadernos do Laboratorio de Formas de Galicia n 5 ), 1978, 142 pp., $24 \mathrm{~cm}$.

VV.AA. Número de patente. Narracións curtas do $3^{\circ}$ premio Modesto Rodríguez Figueiredo. Sada: Ediciós do Castro, 1978, 71 pp., $19 \mathrm{~cm}$. Narradores: Ballesteros, Guisán Seixas, Martínez Oca, et al.

\section{A EDITORIAL CUCO-REI}

Luís Seoane viña xestando desde 1968 Cuco-Rei, revista e editorial. Trátase dun emprendemento cultural pequeno e persoal no cal non intervén Díaz Pardo, que nin siquera buscaba cubrir os gastos ou acadar publicidade de calidade; de feito as tiradas son de autor ou fóra de comercio, exceptuando a de $A$ maior abondamento. Fundouna en 1970 e denomínase igual que a revista de seis páxinas que co editorial do seu único número desencadeou unha liorta entre el e dous membros da Irmandade Galega de Arxentina. O seu encabezamento pode referirse á pregunta do xogo dos nenos, á duración que acadaría a revista, ou ter a explicación en canto se le no editorial, xa que nel Seoane estabelece un símile entre o cuco paxaro e os homes cucos, e reproba o comportamento de certos emigrantes enriquecidos e explotadores, sen precisar en persoa algunha ou grupo. Malia isto, o candidato aspirante a presidir o Centro Galego de Bos Aires sentiuse aludido e, segundo, Maruxa Fernández acertara (Cid Cabido 1994: 174).

Non nos consta se cando o pintor redactou o editorial de Cuco-Rei xa sabía do artigo de Moisés da Presa en A Nosa Terra do mes de setembro, recriminando a Rafael Dieste por empregar o castelán no seu relatorio na inauguración do Museo Carlos Maside e por só escribir dúas obras en galego. Incomodoulle moito porque el sabía dos sacrificios do matrimonio Dieste para vivir con dignidade ${ }^{14}$ e aventuramos que tamén o incomodou porque na organización do dito acto el tivera unha intervención directa. E Seoane contestou os reproches a Dieste desde o programa de radio Galicia Emigrante, que dirixía desde 1954, obtendo unha resposta aínda máis virulenta no número de decembro de A Nosa Terra e ampliando o ataque a el e a Lorenzo Varela.

\section{EDITORIAL DE AUTOR}

As oito publicacións de Cuco-Rei pertencen ao pintor (dúas carpetas de gravado e outras dúas de debuxo: Oito testas e dez paisaxes e Carantoñas e outros debuxos) ou gardan con el unha relación moi estreita. Ademais, nesta editora volve publicar obras nas que unha vez máis bota man das lendas e tradicións populares para fomentar a participación da sociedade nos movementos contra a ditadura franquista. Soma de Craridades (1977) agrupa dous dos seus debuxos para Yunque, a revista que na época da II Républica dirixía Ánxel Fole, catro poemas de Álvaro Cunqueiro e un pequeno ensaio de Montero Díaz, todos datados na primeira metade de 1930. Alba Negri, diplomático arxentino destinado na Alemaña cando Seoane expuxo nese país, é o autor de Ejecución del testamento de Simón Mayor (1978) e para ese libro, o mesmo que para o titulado Homenaxe a Luis Seoane ${ }^{15}$ (1977), o noso artista realizou o deseño e as ilustracións.

En Cuco-Rei en 1972 viu a luz o derradeiro poemario do pintor de Arca; máis tarde, en 1977 e en O castro, Basilio Losada fai a edición da súa obra poética completa e F. Sucarrat un estudo sobre ela. En A maior abondamento o pintor acrecenta o ton épico-narrativo que singulariza a Fardel de exiliado, fai máis prosaica a lingua, busca a inharmonía e eleva o

\footnotetext{
${ }^{14} \mathrm{Na}$ crónica “Exiliados” emitida en Galicia Emigrante o 04/12/1962, Seoane refírese ás frustacións dos refuxiados e di: “...a Rafael Dieste, suspendendo o seu labor criador no encerro dunha oficina editorial desta capital...".

${ }^{15}$ Escrito e ilustrado por Salvador García-Bodaño, Bernardino Graña, Euloxio R. Ruibal, Aurichu Pereira e Enrique Ortiz Alonso. Ademais, contén colaxes realizados con partes de xilografías do propio Seoane.
} 
emigrante á categoría de cuase-heroe; recursos todos eles que confirman canto esclarecerá sobre a súa poesía na resposta á crítica que Molina lle efectuou á antoloxía do grupo Nordés. Dentro da editorial Cuco-Rei, foi o único libro cunha tirada daquela normal (500 exemplares) e distribuído por O Castro, e el mesmo afirmou en repetidas ocasións que o concibiu como resposta a Viaxe ao país dos ananos. A maior abondamento aparece logo do definitivo e acedo enfrontamento entre el e Celso Emilio Ferreiro, unha dura colisión que non conseguiu asolagar a ideoloxía nacionalista e marxista de ambos, que evidenciou desencontros arrastrados ao longo de moito tempo, así como xenreiras que meridianamente se rexistran no epistolario do artista con Díaz Pardo ou Fernández del Riego.

\section{DOUS ÁLBUMS DE GRAVADOS EN MADEIRA DE LUÍS SEOANE}

Os álbums de xilografías Intentando Golpear ideas (1972) e O conde asasino de Sobrado (1971) gravounos cando na Alemaña actuaba a guerriña urbana, en Irlanda o Sein Fein, en USA as panteiras pretas e continuaban as protestas contra a guerra do Vietnam. Mentres, na Galiza se fraguaban as folgas de estudantes na universidade de Santiago e as folgas obreiras de Vigo e Ferrol, e na Arxentina a xuventude encabezaba os combates polas liberdades: desde os Montoneros, en quen Seoane non confiaba por non acreditar no esquerdismo peronista, ao Exército Revolucionario Popular, onde militaban persoas coas cales se relacionou a través de Lorenzo Varela ${ }^{16}$.

En Intentando golpear ideas, a primeira vista percíbese como a policía reprime con fereza os manifestantes. Porén, $O$ conde asasino de Sobrado está dirixido a persoas con capacidade de descifrar o código para realizar a súa lectura, cara a un receptor directo (e á vez receptor ideal) con competencias para descodificar o hipérbato histórico. O nobre cómpre entendelo como un ditador e os rapaces vestidos á moda "hippie" non son o que aparentan, senón mozos enfrontados ao que representa o personaxe portador dun casco militar, conformado a base de planos xeométricos e ríxidos que nos traen á memoria placas de metal, ou de cerámica ou de lousa, materiais cos que está a traballar nese momento.

Mijaíl Bajtín formula o concepto de hipérbato histórico en 1937-38. E coidamos que o noso artista o utiliza xa desde 1938, e en toda a súa produción, incluída a editorial. Luís Seoane bota man do pasado, sexa a prehistoria, o medievo, os anos anteriores a 1936 ou a canto ocorreu na guerra de 1936-39, non só para resaltar os valores e a identidade do pobo galego, senón especialmente para contribuír a extinguir as situacións inxustas e imprimir nos galegos o orgullo de pertencer a unha nación con capacidade de saír para adiante. O hipérbato histórico do pintor, igual que as formulacións do teórico ruso, defínese polo seu carácter dialéctico e dinámico, tanto polo seu código cultural como polo seu horizonte de expectativas.

\section{CONCLUSIÓNS}

O Castro no período de 1963-1968 sigue o patrón do resto das editoras galegas ao desatender a edición de pezas dramáticas. Así, ao contrario do que fixo cos gañadores do concurso organizado polo Pedrón D'Ouro, non edita os autores novos que se dan a coñecer nos premios Abrente de teatro de Ribadavia. Mais subliñamos que nesta primeira etapa saca do prelo dúas obras de interese: Farsas para titeres de Eduardo Blanco Amor e Os Irmandiños de Daniel Cortezón. Este último é un drama ambientado nas loitas entre señores e campesiños no século $\mathrm{XV}$, que nos remite ao $O$ Mariscal de Antón Vilar Ponte e Ramón Cabanillas e a canto esa peza significou dentro do noso rexurdir político-cultural anterior á guerra civil. Tamén a peza $A$ Soldadeira de Luís Seoane.

\footnotetext{
${ }^{16}$ Unha xilografía da guerrilleira Tania e outras baseadas nas protestas en Bos Aires, en 2005 formaban parte dos fondos do Museo Carlos Maside.
} 
Nos primeiros dezaseis anos de edición de O Castro, conflúen a revalorización e a recuperación da xeración do Seminario de Estudos Galegos, incluída a súa faceta política (Discursos Parlamentarios 1931-1933), a obra de autores refuxiados ou de antifranquistas estabelecidos na península, algúns deles antes xa editados por Seoane en Bos Aires en Botella al Mar, en Citania ou na editorial do Centro Galego. Predomina a literatura afastada do formalismo e do estrito intimismo, e xa se adianta o guieiro que caracteriza a editora despois da instauración da democracia: a recuperación da memoria histórica silenciada despois de 1936, feito no que coincide con Cuco-Rei. Trátase dunha liña en conexión coa reclamación da xustiza anamnética ${ }^{17}$.

Por outro lado, enténdese a abundancia de álbums de debuxo e gravado en $\mathrm{O}$ Castro e Cuco-Rei se os consideramos conectados coa circunstancia de seren artistas os seus donos e directores. Nas dúas editoras destaca o grande número de capas deseñadas por Seoane, en parte executadas en Bos Aires e logo remitidas a Galiza, e que son expoñente da súa evolución plástica, neste caso a experimentada entre
1963 e 1978, así como da transversalidade existente na súa produción. Tamén son abundantes as capas de Xosé Díaz, sendo notorio o paralelismo que estabelecen coa pintura que realizaba este nos setenta, con clara influencia da Arte pop. No que atangue á lingua, ningunha das dúas editoriais apostou polo uso exclusivo do idioma galego, unha resolución que $\mathrm{O}$ Castro nunca mudou e que esta editora, como antes Citania en Bos Aires, formaba parte dun proxecto cultural mais amplo.

Por último, convén subliñar que Ediciós do Castro e Cuco-Rei están afastadas dos presupostos e criterios económicos que codefinen as industrias culturais, e que ambas as imprimían na imprenta Moret da Coruña. Sinalamos isto porque Moret facía uso tanto de maquinaria moderna como da que conservaba do primeiro terzo do século XX, unha particularidade moi valorada por Díaz Pardo e Seoane, os dous namorados do xeito artesanal de traballar nas vellas imprentas. Ademais, non se debe esquecer que antes da guerra civil, esa imprenta era propiedade e estaba rexentada por unha familia de republicanos e que nas décadas de 1960 e 1970 pertencía aos seus descendentes.

\section{REFERENCIAS BIBLIOGRÁFICAS}

BAJTín, Mijail (1992): El marxismo y la filosofia del lenguaje. Madrid: Alianza Editorial. (1994): El método formal en los estudios literarios. Madrid: Alianza Editorial.

Cid CABIDo, Xosé (1994): Luís Seoane. Unha fotobiografia (1910-1979). Vigo: Xerais.

Correa CAlderón, Evaristo (1927): Notas para un maxisterio idealista. Lugo: Imprenta Gerardo Castro.

DíAz PARdo, Isaac (1978): Tradición e futuro. Sada: Ediciós do Castro.

(1978b): “Sobre una antología de poesía gallega", La Calle (sec. Lectores), 27/05/1978 [s. p.].

DíAz Rey, María (2002): Antonio Baltar. O compromiso do exilio. Sada: Ediciós do Castro. (2004): Luís Seoane. Notas as súas cartas a Diaz Pardo. Sada: Ediciós do Castro.

\footnotetext{
${ }^{17}$ Entende o recordo e a visibilización dos maltratados por motivos políticos como un acto de xusticia sen caducidade polo paso do tempo e asimilia o seu esquecemento á inxustiza. Defende a vixenza do dano e reclama condenar de xeito efectivo os abusos que sufriron no pasado. $\mathrm{O}$ seu suxeito son tanto as xentes que padeceron persecución ou morte como as actuáis, pois quere resarcir e evitar a repetición da historia (véxase ao respecto Mate Rupérez e Zamora 2012).
} 
FAndiño, Xosé Ramón (2012): A luminosa mirada dos ollos de Isaac (Cadernos Ramón Piñeiro 24). Santiago de Compostela: Centro Ramón Piñeiro para a Investigación en Humanidades.

Fernández Del Riego, Francisco (2002): Cartas de Luis Seoane desde o exilio. Sada: Ediciós do Castro.

Ferreiro, Celso Emilio (1978a): “Escolma ferida”, $A B C$ (sec. Cultura) 30/03/1978, p. 33. (1978b): “Terra de Melide”, $A B C$ (sec. Cultura) 20/07/1978, p. 31.

GonzÁLEz Garcés, Miguel (1964): “Las letras gallegas en 1963”, La Voz de Galicia (Cuaderno especial) 01/01/1964 [s. p.].

Mate Rupérez, Manuel Reyes e José Á. Zamora (eds.) (2012): Justicia y Memoria. Hacia una teoría de la justica anamnética. Madrid: Anthropos.

Molina, César Antonio (1978): “Una falsa muestra de la poesía gallega actual”, La Calle (sec. Libros), 30/04/1978 [s. p.].

SeoAne, Luís (1978): “Resposta a unha crítica de La Calle”, Faro de Vigo (sec. Artes y Letras) 13/08/1978, [s. p.].

VV. AA. (1987): Tradición e Futuro. Sada: Edicións do Castro.

VV. AA. (2008): O Laboratorio de Formas 40 anos despois. A Coruña: Fundación Luís Seoane. 